\title{
Going political - multimodal metaphor framings on a cover of the sports newspaper A Bola
}

\author{
Maria Clotilde Almeida*
}

\begin{abstract}
This paper analyses a political-oriented multimodal metaphor on a cover of the sports newspaper A Bola, sequencing another study on multimodal metaphors deployed on the covers of the very same sports newspaper pertaining to the 2014 Football World Cup in Brazil (ALMEIDA/SOUSA, $2015)$ in the light of Forceville $(2009,2012)$. The fact that European politics is mapped onto football in multimodal metaphors on this sports newspaper cover draws on the interplay of conceptual metaphors, respectively in the visual mode and in the written mode. Furthermore, there is a relevant time-bound leitmotif which motivates the mapping of politics onto football in the sports newspaper A Bola, namely the upcoming football match between Portugal and Germany. In the multimodal framing of the story line under analysis. The visual mode apparently assumes preponderance, since a picture of Angela Merkel, a prominent leader of EU, is clearly overshadowed by a large picture of Cristiano Ronaldo, the captain of the Portuguese National Football team. However, the visual modality of Cristiano Ronaldo's dominance over Angela Merkel is intertwined with the powerful metaphorical headline "Vamos expulsar a Alemanha do Euro" ("Let's kick Germany out of the European Championship"), intended to boost the courage of the Portuguese national football team: "Go Portugal you can win this time!". Thus, differently from multimodal metaphors on other covers of the same newspaper, the visual modality in this case cannot be considered the dominant factor in multimodal meaning creation in this politically-oriented layout.
\end{abstract}

Keywords: Multimodal Metaphors. Sports and Politics. Metaphors in Sports Newspapers.

* Universidade de Lisboa. Faculdade de Letras (FLUL). Centro de Linguística (CLUL). 


\section{An overview on conceptual metaphors and metaphorical blending in Sports newspapers}

Since Lakoff/Johnson's publication of Metaphors we live by (1980, p. 41), we are aware that "metaphors and metonymies are not random but instead form coherent systems in terms of which we conceptualize our experience." This is why conceptual metaphors, such as SPORTS IS WAR, make sense, since sports practices have sprung from the warfare of ancient times. Hence, socio-historical dimensions turn out to be key factors that motivate conceptual metaphors, as is also the case of POLITICS IS CONFLICT (CHARTERIS-BLACK, 2005), grounded in both historical narratives and our everyday experience in the world.

However, our creative minds seem to challenge these coherent systems in terms of which we conceptualize our experience. Life would be extremely dull if we were exclusively governed by a wide range of coherent conceptual metaphors, explained by the formula A IS B. This is not to say that we are not biased by cultural frames in our metaphoric representation of the football world around us. Metaphoric images in football newspaper headlines from A Bola cannot be understood unless we have the cultural key to access each of the Portuguese cultural frames underlying the metaphorical constructions below:

(1) Mas que belo D. Rodrigo!

(2) Arroz de Galo para o Arcebispo

(3) A fava na garganta do Dragão (ver). (Cf. ALMEIDA et al. 2013)

Without activating the cultural frames underlying blended images, one could understand the metaphorical mappings and we would perhaps verge towards falsely understanding the football news headlines, hypothetically as below. However, as they would not fit into the football world, their intended meanings would be lost:

(1a) What a beautiful player????

(2a) The archbishop ate rooster rice????

(3a) The broad bean is stuck in the Dragon's throat?????

Nevertheless, if we take into account the source domains of these metaphorical headlines, which are relevantly activated in different fashions in the conceptual mappings, their meanings are still not fully uncovered by means of the $\mathrm{A}$ is $\mathrm{B}$ formula:

(1b) Source domain: D. Rodrigo (one of the most famous sweets from the Algarve region in Portugal); target domain: Rodrigo (the most prominent football 
player in the match from the Algarve who scored the goal). Metaphoric mapping: Rodrigo seems like D. Rodrigo (?)

(2b) source domain: The Archbishop (metonymical designation for Braga, a city in northern Portugal with many churches), here also metonymically representing Braga's football team; target domain: the rooster - metonymical designation for Barcelos, a city in the north of Portugal famous for the Barcelos Rooster (Galo de Barcelos), acknowledged as the symbol of Portugal, as well as the symbol of Barcelos' football team, Gil Vicente. Metaphoric mapping: The Archbishop/Braga gets the Rooster/Gil Vicente(?)

(3b) source domain: a broad bean is inserted in the Portuguese Christmas cake and so whoever gets the broad bean must pay for the Christmas cake next year; target domain: the Dragon's throat - the Dragon is the symbol of the Oporto Football Club. Metaphorical mapping: The Dragon/FCP undergoes an extremely (life) threatening situation (?)

It is quite clear that the metaphorical mappings above are partly accessed by the metonymical links in the source domains that enhance our partial understanding of the referential facts, but they evidently do not give full access even to inferentially reconstructed meaning framings. This is mainly due to the fact that 1) newspaper news is necessarily time-bound, the FCP match in (3) occurred shortly before Christmas, and thus the broad bean/Christmas cake reference is fully justified (and not merely timeless coherent frames); 2) frame deconstruction based upon knowledge of Portuguese football teams (metonymical mappings and symbols, the Dragon, The Barcelos Rooster included) and Portuguese cultural frames (D. Rodrigo; Galo de Barcelos; the broad bean in the Portuguese Christmas cake) exclusively uncovers cultural dimensions, thus superintending metaphoric mappings; 3) conceptual coherence in the metaphoric mappings hinges both on the communicative context and on the communicative intention, i.e. praising Rodrigo's performance in the match associating him with his birth place, underlining Braga's victory over Gil Vicente as rival teams in Northern Portugal. 4) Without acknowledging the relevance of human blending capabilities in metaphoric architectures, none of these metaphoric framings would be fully understood by sports newspaper readers from a variety of cultural backgrounds.

In fact, advanced blending capacity by humans is responsible for the decoding of blendings, accumulated by cultures over time, such as SPORTS IS WAR 
and POLITICS IS CONFLICT, but also the key element in accessing new blending routes, as is the case of the metaphorical occurrence (1) to (3):

Human children are born with the capacity for advanced blending. Cultures stand ready with products of blending accumulated over time: languages complex gestures, weights and measures and money, stuffed animals, fashions of dress and posture, social rituals, fractions, religion, and so on. Partly because children can form blends of self and other, but also partly because they can form blends of all sorts, children can acquire these culturally developed products of blending. (TURNER, 2014, p. 53)

Due to the fact that cognitive semiotics theory strives upon the notion of mental space, it is imperative to start with its definition in the light of the following conceptual integration paradigm: "Mental Spaces are small conceptual packets as we think and talk for the purpose of local understanding and action." (FAUCONNIER/TURNER, 1998:137).

Hence, when we think and talk, we operate on the basis of a network of mental spaces mapped onto each other. However, the difference between Fauconnier/ Turner's conceptual integration model $(1998,2002)$ and the (six) Mental Space Network Model (BRANDT, 2004; BRANDT/BRANDT, 2005) lies within the fact that, in the former, blends result from mappings between two Input Spaces levelled by a Generic Space, whereas in the latter mappings unfold throughout mental spaces of different nature.

In Almeida et al. (2013), it was claimed that only the cognitive semiotics model, the Mental Space Network Model (BRANDT, 2004; BRANDT/BRANDT, 2005), is powerful enough to provide explanations for the blended architectures in the sports newspaper A Bola, since it hinges on a dynamic interplay between the real world as experienced and a mental construction of it with the intervention of our culture-bound imaginative capabilities: “(...) especially cognitive semiotics, intends to study how representational meaning can be modelled as dynamically related both to the imaginary and to the experiential world in which meaning is meaningful." (BRANDT, 2005, p. 1585).

Stressing the virtuosities of the cognitive semiotics model in unveiling the dynamics of creative blending processes in advertising, Veale, Feyaerts and Forceville (2013, p. 48) claim that: 
To account both for the context in which a blend is created and for the communicative goals that a blend is to achieve in this context, Brandt \& Brandt (2002) add an extra two spaces to the basic model a reference space and a presentation space. In this extended view, the reference space makes available to the blend those elements which are contextually relevant at the time of creation; thus, if an advertising copywriter is planning a print campaign for a particular make of a car, the reference space will contain the elements that are relevant to the car, its makers, its customers, and so on. The presentation space provides complementary knowledge concerning the communicative goal of the blend's creator; thus, in the advertising context above, the space would contain the qualities of the car that one wishes to highlight (or hide) in the blend, the history of the manufacturer and other branding elements, the benefits of car ownership, problems with a competing product, and so on. These additional spaces nicely capture the context-sensitive and the goal-driven nature of creative blending. (VEALE; FEYAERTS; FORCEVILLE, 2013, p. 48, our emphasis.)

Needless to say, the six-mental-space model is the most comprehensive approach targeting a time-bound enunciation situation that unfolds into mappings of a Reference Space into a Presentation Space, giving rise to a Virtual Space (sometimes re-conceptualized by counterfactual elaboration), superintended by a cultural scenario of relevance. This results in a Meaning Space, inferentially projected onto the enunciation space, the Base Space, as depicted below.

Almeida (2011, p. 2) has claimed that each semiotic act is endowed with a communicative-bound perspective, thus rendering it conceptually unique in a specific communicative setting:

\section{1 "The First Supper" as a counterfactual blending occurrence}

From our vast corpus of metaphoric blended images, gleaned from the Portuguese Sports newspaper A Bola from 2002 to 2013, it caught our attention that many of the metaphoric occurrences spring from the conceptual metaphor FOOTBALL IS RELIGION. There is, however, one metaphoric blend that deserves to be fully dissected here:

(4) A Primeira Ceia - Jesus e os seus "Apóstolos" continuam invencíveis na préépoca e somam Terceira vitória consecutiva que valeu o primeiro troféu da época" (A Bola, 17.07.2009) (transl: "The First Supper" - Jesus and his "Apostles” continue to be invincible in the pre-season and sum up their Third consecutive victory, which won them their first trophy of the season". 
It comes as no surprise that this occurrence constitutes a blended scenario since it feeds on a mapping of the religious frame, Christ's Last Supper, onto the referred episode of the first meeting that the former Benfica football coach held with his players, metaphorically conceptualized as "Apostles", to praise the football coach's work routines.

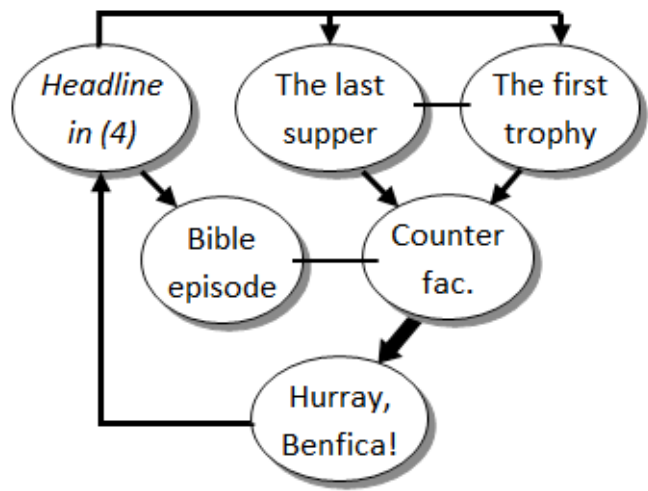

DIAGRAM 1 - Cognitive semiotics analysis of A Primeira Ceia

In fact, it is not simply a blended metaphoric image but, in fact, a counterfactually architectured one, since it clearly strays away from the widely known biblical episode of the "Last Supper." In fact, this specific biblical episode has been reconceptualized as the "First Supper", a newly created blend clearly inspired by the biblical episode. As argued by Holme (2004, p. 19), counterfactual statements are typically prefaced by "if and only if" and: "[they] invoke a world that is not regulated by the same facts as our own and where their statement becomes one of possibility."

\section{Multimodal metaphors in the sports newspaper A Bola}

According to Forceville (2009, p. 5) the multimodal approach to metaphors necessarily involves all modes of meaning-making: visual signs, written signs, sound, music, gesture, smell and touch.

However, one should bear in mind that the analysis of newspaper covers 
exclusively targets the creative metaphoric interplay of visual and written signs, with the purpose of uncovering the architecture of a blended meaning-in-context. Taking multimodal metaphors in advertising as a point of departure, the core of the analysis should hinge "(...) not so much in the content of pertinent information (which in advertising is often predicable or even banal), but in conveying the information in unexpected form - which in the present cases means in non-verbal or multimodal ways." (FORCEVILLE, 2012, p. 114).

However, Forceville (idem) has distinguished several mapping scenarios from source to target domains in multimodal metaphors in adverts, namely: 1) the source domain in the visual and musical modalities are widely known, as is the case of mapping the Easy Rider frame onto the Philips coffee machine; therefore, it is considered to be a source-before-target-framing; 2) the source domain in the visual mode is very improbable, namely, the Mona Lisa frame onto the OrangutanAmsterdam zoo-framing, whereby the written mode is essential for the addressee to comprehend the intended message; 3) and pictorial metaphors themselves, where mappings between source and target domains of the multimodal metaphors that rely heavily upon visual similarities are easily perceived by the addressees.

Since sports newspaper cover layouts are very similar to advertisements in the printed media, our analysis of multimodal metaphors in the sports media draws on considerations of mappable features between source and target domains, involving verbal and visual modalities, paying special attention to image-text composition framings. Moreover, special attention must be paid to the overpowering of the pictorial mode over the written mode, or vice-versa, or alternatively to the balanced interplay of both modes.

In our previous analysis of multimodal metaphors on the sports newspaper covers of "A Bola" (ALMEIDA/SOUSA 2015), the conceptual metaphor FOOTBALL IS RELIGION stood out, as shown below: 


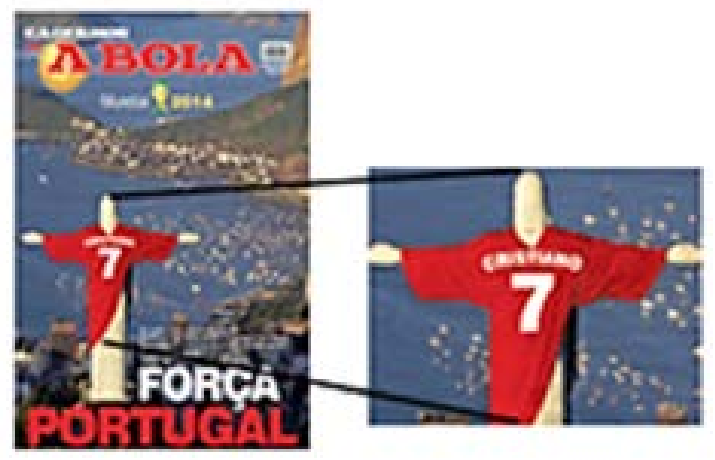

FIGURA 1 - Multimodal metaphor Força, Portugal (transl., Go, Portugal!) Source: A Bola PT

In the above multimodal assemblage on the cover of the sports newspaper $\mathbf{A}$ Bola, issued shortly before the Football World Cup in Brazil in 2014, Christ the Redeemer, a worldwide known statue in Rio de Janeiro wears Cristiano Ronaldo's football team shirt, the captain of the Portuguese national team. Hence, the source and target of the multimodal metaphor are blended in the visual mode. Although the intended meaning of the multimodal metaphor "Go, Portugal!" is identified in the written mode, there is no doubt that the pictorial mode overpowers the written mode in the image-text interface. Notice that this blended multimodal assemblage is far from expected, since it architectures a new blended scenario, in which "God is Portuguese", a counterfactual statement challenging the culture-bound frame Brazilians cling to in all life-challenging situations but, above all, in football match related scenarios, namely, "God is Brazilian".

As occurs on another A Bola cover depicting the victorious performance of the Portuguese national football team, highlighting Cristiano Ronaldo's brilliant performance in the Sweden-Portugal match, the interplay between source and target of metaphors is evenly present in both pictorial and written modes. Upon analyzing both modes independently, it is obvious that the pictorial mode displays Cristiano Ronaldo's cry of joy, celebrating Portugal's victory over Sweden. 


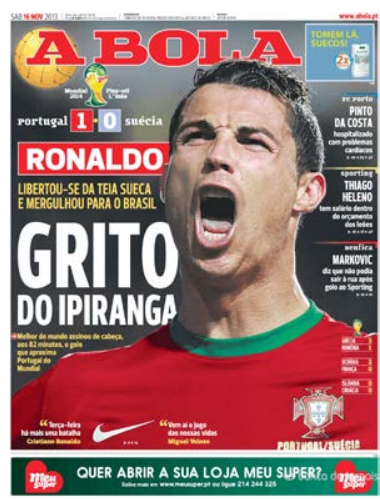

FIGURA 2 - Multimodal metaphor Grito do Ipiranga Source: A Bola PT

However, we have argued that the blended scenarios arise out of the assemblage of the pictorial mode with the written mode, which conveys the counterfactual conceptualization frame. Moreover, we cannot solve the whole puzzle of the blending process without evoking the historical frame underlying the headline, "O Grito do Ipiranga" ("The Ipiranga cry"), which specifically signals a manifestation of joy, celebrating Brazil's independence from the Portuguese crown in colonial times. On architecturing a newly blended scenario, in which it is Ronaldo who voices the "Ipiranga cry" to celebrate the historical fact that Portugal has conquered the right to play in the Football World Cup in Brazil, the historical frame becomes clearly subverted but in a meaningful way, since Portugal has earned the right to come back to Brazil and play in the Football World Cup, which is in itself a historical fact.

The circumstance that a famous historical fact in Portugal-Brazil history is twisted to please the Portuguese football newspaper readers can only be identified from the cognitive semiotics perspective, because it deals with counterfactual meaning elaboration emerging from the combination of facts with imagination, in particular enunciation frames (BRANDT, 2004).

The blended layout on the cover is activated from Base Space - the multimodal designed cover of A Bola - and the metaphorical image unfolds from the mapping of the Presentation Space "Grito do Ipiranga" onto the Reference Space of Portugal's win over Sweden, which grants the Portuguese National team the right to partcipate in The Football World Cup in Brazil. In the Virtual Space, Portugal's win as "The Ipiranga Cry" is validated from the Relevance scenario, referring 
to historical celebrations of joy, compressed in time $\left(18^{\text {th }}\right.$ compressed with $21^{\text {st }}$ century) and space, namely, Brazil away from Portugal's domination and Portugal on their way to the upcoming participation in the Football World Cup in Brazil. The purposeful intent of praising Portugal's national football team performance, metonymically represented by the captain of the national team, Ronaldo, is purported by multimodal means, in which there is a balanced interplay between the pictorial and written mode.

\section{Multimodal analysis of the "Going-political-framing" in the sports newspaper}

A Bola Our present multimodal analysis targets a cover of the sports newspaper A Bola, which we have identified as a "The Going-Political-framing", drawing on blending international politics into football, i.e. by printing Angela Merkel's picture side by side with Cristiano Ronaldo's picture on the front page. If we ask ourselves what is the relationship between a prominent EU International politician and a prominent Portuguese football player, we arrive at the conclusion that there is no evident connection in sight, other than the fact that they are widely known public figures. So, how can it be that the mostly widely read sports newspaper in Portugal prints this unexpected layout on the front page? It must necessarily be considered an artful layout with a very specific communicative purpose by unexpectedly blending these two important figures from disconnected domains of human social activity.

It has been reported that the verbal modality on the sports newspaper cover must be one of the key elements for deconstructing the blended meaning. Yet another meaningful key element for accessing the intentionally conveyed meaning relies upon the different sizes of Merkel's and Ronaldo's pictures, since the picture size draws upon the conceptual metaphor of power - IMPORTANT IS BIG - which is fundamental in the visual perception of the covers. Lastly, we must be able to correctly access the intended meaning by interpreting the very different facial expressions on Merkel's and Ronaldo's pictures, namely, surprise or amazement in Merkel's face, which is clearly overruled by Ronaldo's glance of assertiveness and contempt. Moreover, since the intended harsh political criticism is grounded in the painful experience of long-term austerity, that is, the economic measures that the EU imposed on the Portuguese people over the past few years, this blended cover emerges from an "actual situation of concern", as postulated for metaphoric blends by BRANDT and BRANDT (2005). 
The fictive confrontation is staged, in the multimodal metaphoric blend, by metonymically selecting the photos of the two most prominent actors on each side of the imagined conflict, namely Cristiano Ronaldo for Portugal and Angela Merkel for the EU, in a very suggestive TOP/Ronaldo-DOWN/Merkel visually architectured layout.

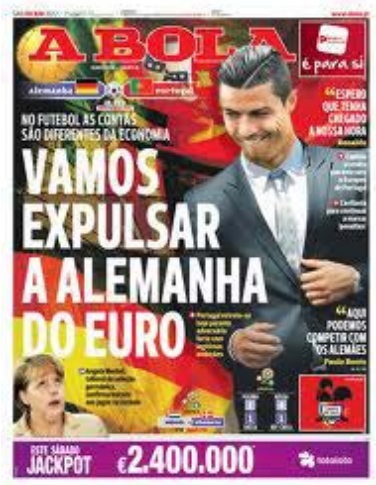

FIGURA 3 - Multimodal metaphor Vamos Expulsar a Alemanha do EURO Source: A Bola PT

In fact, this multimodal blended assemblage feeds on metaphors of power (GOATLY, 2007, p. 35-39), namely, IMPORTANT IS BIG, POWER/CONTROL IS ABOVE; IMPORTANCE/STATUS IS HIGH and ACHIEVEMENT/SUCCESS IS HIGH, and, as such, purports a fictive domination-dominated relationship in which:

Cristiano Ronaldo is bigger than Angela Merkel;

Cristiano Ronaldo overpowers Angela Merkel;

Cristiano Ronaldo's status is more important than Angela Merkel's;

Cristiano Ronaldo's success is higher than Angela Merkel's.

Physical/psychological dominance in the multimodal metaphoric blended cover is staged by Cristiano Ronaldo's grinning face, looking downwards at Angela Merkel, who is looking up at Ronaldo with a surprised and somewhat fearful facial expression.

No doubt that this A Bola cover activates the conceptual metaphor of INTERNATIONAL POLITICS IS WAR: two teams, namely northern European countries, 
where the winning team, imposing austerity measures on southern European countries plus Ireland (unfairly called PIGS), the losing team.

Notice that the counterfactual blend emerges with crystal-clear intention of staging Portuguese-German warfare, in which the Portuguese are on the winning side, in the written mode: "Vamos expulsar a Alemanha do Euro" (Let's kick Germany out of the European Football Championship), clarified in the subtitle "No futebol, as contas são diferentes da economia. Aqui podemos competir com os alemães." ("In football, mathematics is quite different from economics (...). Here, we can compete with the Germans).

Hence, the cognitive semiotic analysis of the written mode stages another world-order in the football sphere, whereby the mapping of POLITICS onto FOOTBALL, i.e. the relationship of dominance of Germany over Portugal in the economic domain, is clearly subverted in the blended image, in which Portugal's national football team is explicitly encouraged to overpower Germany's national football team performance in the upcoming match.

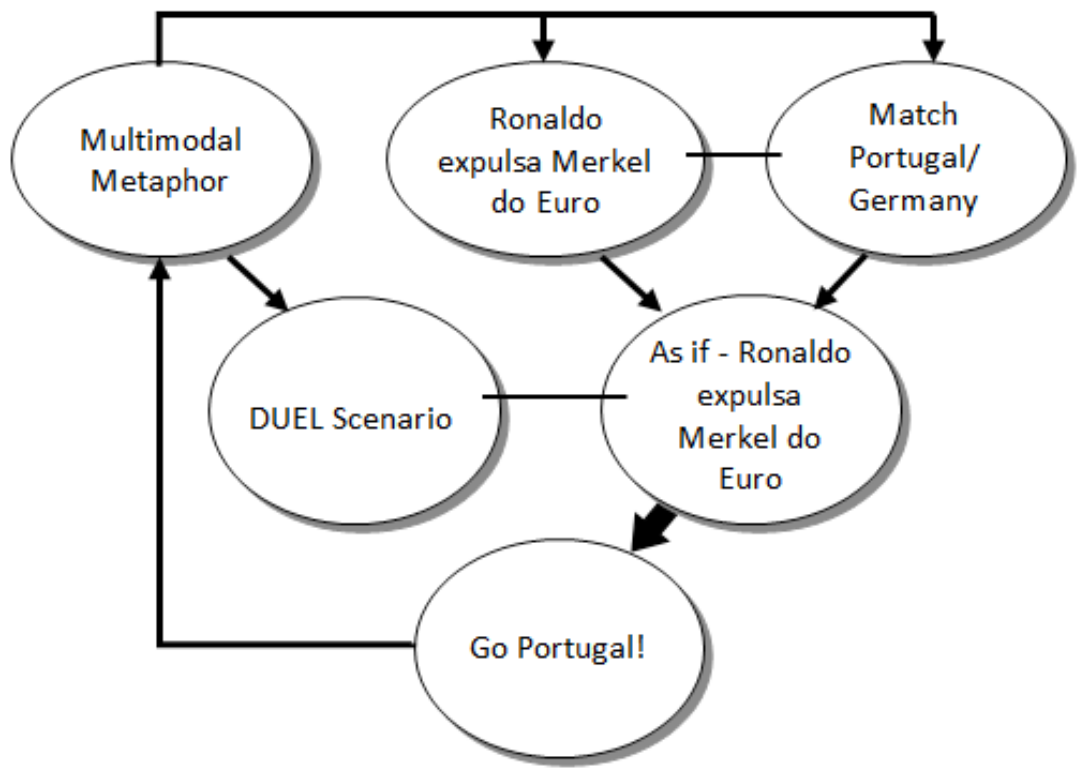

DIAGRAM 2 - Cognitive semiotics analysis of Vamos Expulsar a Alemanha do Euro (Let's kick Germany out of the European Football Championship)

Source: Elaborated by the author. 


\title{
Final Remarks
}

Upon analysis of the seemingly improbable GOING-POLITICAL MULTIMODAL METAPHOR on a cover of the Portuguese sports newspaper A Bola, as compared to the multimodal analyses of an array of covers from the same newspaper (ALMEIDA; SOUZA 2015), some differences must be highlighted: the staging of a conflict between Angela Merkel and Cristiano Ronaldo, dwelling on the interplay of conceptual metaphors of POWER in the visual modality, harmoniously blended with conceptual metaphors of WAR in the written mode. Ronaldo overpowers Merkel in the visual mode and the Portuguese football team is expected to win the upcoming football match against the German football team in the written mode. Hence, the blended multimodal cover relies on the balanced interplay between the visual mode and the written mode.

\section{Rumo à política: metáforas multimodais numa capa do jornal A Bola}

\begin{abstract}
Resumo
O presente artigo analisa as mensagens políticas veiculadas por metáforas multimodais numa capa do jornal desportivo A Bola, na senda de um outro estudo sobre metáforas multimodais em capas desse mesmo jornal desportivo relativas ao Campeonato Mundial de Futebol no Brasil em 2014 (ALMEIDA; SOUSA 2015), à luz de Forceville (2009, 2012). A imagem multimodal analisada emerge da confluência das metáforas conceptuais de poder no modo visual e de guerra no modo escrito, sendo motivada por um leitmotif temporal, o jogo de futebol entre as selecções de Portugal e da Alemanha, que decorre por altura da imposição das medidas de austeridade pela UE a Portugal. $\mathrm{Na}$ arquitectura multimodal do enredo, o modo visual assume aparentemente preponderância com uma fotografia, em tamanho pequeno, de Angela Merkel, figura política responsável pelas políticas europeias de austeridade, claramente dominada por uma fotografia de Cristiano Ronaldo em tamanho grande, capitão da selecção portuguesa de futebol. Contudo, a modalidade visual é reforçada pela modalidade escrita "Vamos expulsar a Alemanha do Euro", que consubstancia um incitamento à luta pela vitória: "Vamos Portugal - podemos ganhar à Alemanha desta vez". Desta forma, diferentemente da maioria das metáforas multimodais nas capas dos jornais desportivos que tínhamos analisado, a modalidade visual não pode ser considerada o factor dominante na construção da mensagem multimodal nesta capa do jornal de cunho político.

Palavras-chave: Metáforas multimodais. Desporto e política. Metáforas nos jornais desportivos.
\end{abstract}




\section{References}

ALMEIDA, M.C. A arte de ser metáfora: estudo interlinguístico portuguêsalemão de índole cognitiva". In: Polifonia - Revista do Grupo Universitário de Investigação em Línguas Vivas da Universidade de Lisboa - 2. Lisboa: Colibri, 1999. p. 59-74.

ALMEIDA, M.C. More about blends: blending with proper names in the Portuguese media. In: GONÇALVES, M.; SILVA, A.; TORRES, A. (Orgs.). Linguagem, cultura e cognição: estudos de linguística cognitiva. Coimbra: Almedina, 2004. p. 145-158.

ALMEIDA, M.C. A poética do futebol: análise de representações mescladas à luz do paradigma das redes de espaços mentais. In: FIGUEIREDO, O.; SILVA, F.; RIOTORTO, G. (Org.). Dar a palavra ao mundo. Estudos de Homenagem ao Professor Doutor Mário Vilela. Porto: FLUP, 2005. p. 557-570.

ALMEIDA, M.C. Blending the pheno-world with fiction: the cognitive semiotics view. In: ALMEIDA, M.C.; LIMA, J.P.; SIEBERG, B. (Org.). Questions on the linguistic sign. Lisboa: Colibri, 2006a. p. 49-64.

ALMEIDA, M.C. Blend-Bildungen - und was dahinter steckt. In: SCHMIDTRADEFELDT, J. (Org.). Portugiesisch kontrastiv gesehen und Anglizismen weltweit. Rostocker Romanistische Arbeiten 10, Berlin: Peter Lang, 2006 b. p. 241-259.

ALMEIDA, M.C. A relevância da relevância em mesclagens. In: Costa, A.; Duarte, I. (Orgs.). Nada na linguagem lhe é estranho. Porto: Afrontamento, 2012. p. 565578.

ALMEIDA, B.; SOUSA, B. Helden-Metaphern in der deutschen und portugiesischen Sportpresse. Revista de Estudios Filológicos Alemanes. Revista del Grupo de Investigación Filologia Alemana v. 20, Sevilla: Fénix Editora, 2010, p. 243-256.

ALMEIDA, M.C.; ÓRFÃO, P.; SOUSA, B.; TEIXEIRA, S. Jogar futebol com as palavras. Imagens metafóricas no jornal A Bola. Lisboa: Colibri, 2013.

ALMEIDA, M.C.; CARDOSO, T.; SOUSA, B. Metaphors in rap texts. Local architecturings of political agendas. In: SILVA, A.S. et al. (Org.). Comunicação política e económica. Dimensões cognitivas e discursivas. Braga: Aletheia, 2013. p. $127-140$.

ALMEIDA, M. C.; SOUSA, B. From monomodal to multimodal metaphors in the sports newspaper A Bola. Revista Brasileira de Linguística Aplicada. Special Issue Metaphor and Metonymy in Social Practices (Gibbs, R.W.; Ferreira, L., eds.), UFMG, 2015, p. 403-420. Available at: http://dx.doi.org/10.1590/1984639820157138. Accessed on April 20, 2016. 
ALMEIDA, M. C.; SOUSA, B. Worldmaking in Rap-predators, fighters, salvagers - a multimodal approach. In: FERNANDES, C. (Org.) Multimodality and performance. Newcastle: Cambridge Scholars Publishing, 2016, p.23-37.

BRANDT, P. A. Spaces, domains and meaning. Essays in cognitive semiotics. Bern: Peter Lang, 2004.

BRANDT, P. A. Mental spaces and cognitive semantics: A critical comment". Journal of pragmatics, Amsterdam v. 37, n. 10 (Special Issue on Conceptual Blending Theory), p. 1579-1594, 2005.

BRANDT, L; BRANDT, P. A. Making sense of a blend. A cognitive semiotics approach to metaphor. IN: Annual review of Cognitive Linguistics (F. Ruiz de Mendonza Ibañez, ed.), v. 3, Amsterdam/Philadelphia: John Benjamins, p. 216-249, 2005 .

CHARTERIS-BLACK, J. Politicians and rhetoric: the persuasive power of metaphor. Basingstoke: Palgrave-Macmillan, 2005.

FORCEVILLE, C. Non-verbal and multimodal metaphor in a cognitivist framework: agendas for research. In: FORCEVILLE, C.; URIOS-APARISI, E. (Orgs.), Multimodal metaphor. Berlin: de Gruyter, 2009. p. 19-44.

FORCEVILLE, C. Creativity in pictorial and multimodal advertising metaphors. In: JONES, R. (Org.), Discourse and creativity. Harlow: Pearson, 2012. p. 113-132.

GOATLY, A. Washing the brain. Metaphor and hidden ideology. Amsterdam: J. Benjamins, 2007.

KÖVECSES, Z. Metaphor. A practical introduction. Oxford: Oxford University Press, 2002.

LAKOFF, G.; JOHNSON, M. Metaphors we live by. Chicago: The University of Chicago Press, 1980, 2003.

SOUSA, B. Mapeando mundos no mundo do futebol: abordagem semióticocognitiva dos média alemães, 2011, p.593, Dissertation (Ph.D. in German Linguistics). Faculdade de Letras, Lisboa.

TURNER, M. The origin of ideas. Blending, creativity and the human spark. Oxford, NY: Oxford University Press, 2014.

VEALE, T.; FEYEARTS, K.; FORCEVILLE, C. E unis pluribum: using mental agility to achieve creative duality in word, image and sound. In: VEALE, T.; FEYAERTS, K.; FORCEVILLE, C. (Orgs.). Creativity and the agile mind. A multi-disciplinary study of a multi-faceted phenomenon. Berlin \& NY: De Gruyter, 2013. p. 37-56.

Recebido em 31/03/2016. Aceito em 13/07/2016. 